\title{
CONFIRMATORY FACTOR ANALYSIS INTELLECTUAL CAPITAL, KNOWLEDGE MANAGEMENT AND COMPETITIVE ADVANTAGE OF MSMES
}

\author{
Dr. Suharto SM \\ Master of Management \\ Wisnuwardhana University Malang, Indonesia \\ E-mail: opik.unidha@gmail.com \\ M. Taufiq Noor Rokhman \\ Accounting Study Program \\ Faculty of Economics and Business, \\ Wisnuwardhana University Malang, Indonesia \\ Ahmad Jamil \\ Student Master of Management \\ Wisnuwardhana University Malang, Indonesia
}

\begin{abstract}
Micro, Small and Medium Enterprises (MSMEs) are the most important pillars in the Indonesian economy and the high number of MSMEs in Indonesia cannot be separated from the existing problems. The problems faced by MSMEs cause the low competitiveness faced by MSMEs. The competitive advantage generated by MSMEs comes from superior resources which are reflected in the company's intellectual assets (intellectual capital). SMEs that can create a competitive advantage must have different resources from their competitors. One of the resources that can be highlighted is knowledge resources. The purpose of this study is to analyze confirmatory factors intellectual capital, knowledge management and competitive advantage. Analysis of the data used in the study using confirmatory factor analysis (CFA) techniques, the results of the study show that the indicator that is considered to have the largest or strongest contribution in forming the intellectual capital variable is human capital. The indicator that is considered to have the largest or strongest contribution in forming the Knowledge Management variable is the use of knowledge and the indicator that is considered to have the largest or strongest contribution in forming the variable of competitive advantage is not easy to replace.
\end{abstract}

Keywords: Intellectual Capital, Knowledge Management and Competitive Advantage.

JEL Classification Codes: O34, D83, L15, L26.

\section{INTRODUCTION}

Micro, Small and Medium Enterprises (MSMEs) are the most important pillars in the Indonesian economy. Based on data from the Ministry of Cooperatives and SMEs, in 2020, the number of MSMEs currently reaches 64.2 million with a contribution to GDP of $61.07 \%$ or worth $8,573.89$ 
trillion rupiah. The contribution of MSMEs to the Indonesian economy includes the ability to absorb $97 \%$ of the total workforce and can collect up to $60.4 \%$ of the total investment. However, the high number of MSMEs in Indonesia is also inseparable from the existing problems. Problems faced by MSMEs among others: The internal factors of batik SMEs such as lack of capital, limited human resources (HR), lack of mastery of science and technology, weak business networks and market penetration capabilities. Meanwhile, external factors for SMEs such as: the business climate is not yet fully conducive, limited facilities and infrastructure, implications for regional autonomy, implications for free trade, the nature of products with short lifetimes, and limited market access.

The problems faced by MSMEs cause the low competitiveness faced by MSMEs. Barney and Clark (2007) revealed that one of the approaches used to have a competitive advantage is the Resource-Based View (RBV). In general, RBV focuses on understanding the potential of organizational resources and capabilities. RBV is defined as a set of strategic assets that are rare, valuable, imperfectly imitable, and non-substitutable (Meso and Smith, 2000). RBV is seen as a strategy in achieving organizational competitive advantage through the identification of heterogeneous organizational resources. This resource-based approach aims to classify organizational strategic resources that have the most potential to create competitive advantage (Akio, 2005).

Ireland, et al. (2003) suggests that if the company can manage its resources and capabilities in a strategic and structured manner, the competitive advantage will increase. Bharadwaj et al. (1993) revealed that competitive advantage is measured by indicators of uniqueness, rare, not easy to imitate, not easy to replace, and competitive prices. Bratic, (2011) reveals that competitive advantage is measured in four indicators, namely: Price, Quality, Deliver Dependability, product innovation and time to market. Peng, et al. (2011) priority measurement consists of cost priority, quality priority, deliver priority, flexibility priority and innovation. Michalic and Buhalis (2013) use image, quality, differentiation, contact and price in seeing competitive advantage. Research conceptual framework $\mathrm{Li}$, et al.

Based on the RBV theory, the competitive advantage generated by MSMEs comes from superior resources which are reflected in the company's intellectual assets (intellectual capital). Intellectual capital is knowledge, application of experience, and professional skills that are converted into values that can give companies a competitive advantage. Chahal and Bakshi (2015) describe intellectual capital as an intangible asset which is a combination of competencies, knowledge, abilities, skills, experience, and customer relationships that can give the company a superior position in the market. Wang and Chang (2005) argue that intellectual capital is a fundamental determinant of the future development of company value and the company's current and future competitiveness. Bonus and Fitz (2002), show that the three elements of intellectual capital are interrelated and operate in an interactive or collaborative manner to form a strong intellectual capital base that creates or influences a firm's competitive position.

Williams (2001) reveals that intellectual capital is information and knowledge that is applied in work to create value. Bontis et al. (2000) identified three main constructs of intellectual capital, namely: human capital, structural capital, and customer capital. Guthrie and Petty (2000) state that the components of Intellectual Capital are employee competence, internal structure, and external structure.

SMEs that can create competitive advantage must have different resources from their competitors. One of the resources that can be highlighted is knowledge resources. Bratianu and 
Orzea (2010) find that knowledge creation is a dynamic capability that enables companies to achieve. Barclay and Murray (2002) define knowledge management as a business activity that has two important aspects, namely treating the knowledge component in business activities which is reflected in strategies, policies, and various corporate practices as a whole.

Honeycutt (2000) suggests that the main processes in knowledge management include the creation of knowledge (creation), the use of knowledge (utilization) and knowledge sharing (sharing). According to Gold, et al, (2001); Mills and Smith (2010) there are four processes in knowledge management, namely: knowledge acquisition, knowledge conversion, knowledge application and knowledge protection. Based on the research background, it is interesting to conduct a confirmatory factor analysis study intellectual capital, knowledge management and competitive advantage for SMEs

\section{Intellectual Capital}

\section{THEORITICAL REVIEW}

Intellectual capital is defined as knowledge resources in the form of employees, customers, processes, or technology that the company can use in the process of creating value for the company (Bukh et al., 2005). Intellectual capital is a resource owned by a company that will provide benefits in the future. In general, the elements in intellectual capital are divided into three categories of knowledge, namely knowledge related to employees (human capital), knowledge related to customers (customer capital or relational capital), and knowledge related to the company (structural or organizational capital). ), these three categories make up Intellectual Capital (Bontis et al., 2000).

Boekestein, (2006) says the components of intellectual capital are as follows: 1. Human Capital is the expertise and competence possessed by employees in producing goods and services and their ability to relate well to customers. 2. Structural Capital is the infrastructure owned by a company in meeting market needs. 3. Customer Capital are people associated with the company, who receive the services provided by the company.

\section{Knowledge Management}

According to Chen et al. (2010), knowledge management is a process of human activity that is related to knowledge, but does not deal with the nature of different types of knowledge, or the relative importance of different knowledge in an organization. Barclay and Murray (2002) define knowledge management as a business activity that has two important aspects, namely treating the knowledge component in business activities which is reflected in strategies, policies, and various corporate practices as a whole. Honeycutt (2000) suggests that the main processes in knowledge management include the creation of knowledge (creation), the use of knowledge (utilization) and knowledge sharing (sharing). According to Gold, et al, (2001); Mills and Smith (2010) there are four processes in knowledge management, namely:

\section{Competitive Advantage}

Bharadwaj et al. (1993) explained that competitive advantage is the result of implementing strategies that utilize various company resources. Unique skills and assets are seen as sources of competitive advantage. Competitive advantage is defined as a strategy benefit from companies that cooperate to create a more effective competitive advantage in the market. This strategy must be designed to achieve a sustainable competitive advantage so that the company can dominate in both the old and new markets. 
Bharadwaj et al. (1993) revealed that competitive advantage is measured by indicators of uniqueness, rare, not easy to imitate, not easy to replace, and competitive prices. Bratic (2011) reveals that competitive advantage is measured in four indicators, namely: Price, Quality, Deliver Dependability, product innovation and time to market. Penget et al. (2011) priority measurement consists of cost priority, quality priority, deliver priority, flexibility priority and innovation. Michalic and Buhalis (2013) use image, quality, differentiation, contact and price in seeing competitive advantage. The conceptual framework of research by Li et al. (2006) developed indicators for measuring competitive advantage, namely: price/cost, quality, delivery dependability, product innovation and time to market.

\section{Population and Sample}

\section{METHOD}

The population in this study were SMEs located in Malang City and registered with the Malang City Cooperatives and SMEs Service, amounting to 1,136 SMEs. To determine the size of the sample taken from the research population using the formula proposed by Slovin in Mustafa (2010: 90) with a 90\% confidence level with a value of $\mathrm{e}=10 \%$, the size of the sample used is 100 SME owners.

\section{Operational Definition and Measurement of Variables}

This study was designed as an empirical study. To test the proposed hypothesis and operational variables systematically, it will be shown in Table 1 below:

Table 1. Variables and Indicators

\begin{tabular}{|c|c|c|c|}
\hline No & Variable & Indiactor & Source \\
\hline \multirow[t]{3}{*}{ '1 } & \multirow[t]{3}{*}{ Intellectual Capital } & 1. Human capital & \multirow{3}{*}{$\begin{array}{l}\text { Bontis et al. } \\
(2000), \text { Boekestein, } \\
(2006)\end{array}$} \\
\hline & & 2. Structural capital & \\
\hline & & 3. Customer capital & \\
\hline \multirow[t]{4}{*}{2} & \multirow[t]{4}{*}{ Knowledge management } & 1. Knowledge application & \multirow{4}{*}{$\begin{array}{l}\text { Gold, et al, (2001) } \\
\text { Mills and Smith (2010). }\end{array}$} \\
\hline & & 2. Knowledge creation & \\
\hline & & 3. Knowledge dissemination & \\
\hline & & 4. Knowledge utilization & \\
\hline \multirow[t]{5}{*}{3} & \multirow[t]{5}{*}{ Competitive Advantage } & 1. Uniqueness & \multirow{5}{*}{$\begin{array}{l}\text { Bharadwaj et al., (1993), } \\
\text { Bratic, (2011) and } \\
\text { Michalic and Buhalis } \\
(2013)\end{array}$} \\
\hline & & 2. Rarely found & \\
\hline & & 3. Not easy to imitate & \\
\hline & & 4. Not easy to replace & \\
\hline & & 5. Competitive price & \\
\hline
\end{tabular}

The research variables were measured using a Likert scale model, which measured attitudes by stating their agreement or disagreement with the questions posed with a score of 5 (SS = Strongly Agree); 4 ( $\mathrm{S}=$ Agree); 3 (CS=Simply Agree); 2 (TS=Disagree); and 1 (STS=Strongly Disagree).

\section{Analysis Method}

Analysis of the data used in the study used confirmatory factor analysis (CFA) techniques. While 
CFA is used for research where the researcher already has knowledge about the structure of the underlying latent variables. Based on theory or empirical research, the person concerned makes postulates/assumptions/reasoning relationships between the observed measurements and the previous underlying factors. Because it only focuses on the relationship between the factors and all the variables measured, in particular CFA is called a measurement model in the perspective of Structural Equation Modeling (SEM).

\section{RESULTS}

The presentation of the research results begins with the respondent's profile, namely: 100 owners Micro, Small and Medium Enterprises (SMEs) located in Malang City, East Java, Indonesia. Respondent profiles are disclosed in Table 2.

Table 2. Profile of Respondents

\begin{tabular}{|l|c|c|}
\hline \multicolumn{1}{|c|}{ Respondent profile } & Number of people) & \% \\
\hline Gender & & 45 \\
\hline Man & 45 & 55 \\
\hline Woman & 55 & \\
\hline Age & & 58 \\
\hline $30-40$ Years & 58 & 33 \\
\hline $41-50$ Years & 33 & 18 \\
\hline 51 years and over & & 45 \\
\hline Last education & 18 & 37 \\
\hline junior high school & 45 & \\
\hline high school & 37 & 15 \\
\hline Bachelor degree) & & 22 \\
\hline Experience as an entrepreneur & 9 & 54 \\
\hline $1-5$ years & 15 & \\
\hline 6-10 years & 22 & 9 \\
\hline $11-15$ years old & 54 & 18 \\
\hline 15 years and over & & 25 \\
\hline Long standing business & 9 & 48 \\
\hline $1-5$ years & 18 & \\
\hline 6-10 years & 25 & \\
\hline $11-15$ years old & 48 & \\
\hline 15 years and over & & \\
\hline
\end{tabular}

Based on Table 2, it can be explained that the characteristics of the respondents in terms of gender indicate that respondents who own SMEs in Malang are dominated by women, aged 41-50 years with a high school education level, having experience as an entrepreneur for 15 years and over and a business managed for 15 years and over.

\section{Instrument Testing}

The results of testing the validity and reliability of the instrument can be seen in Table 3 below: 
Table 3. Test Results of Instrument Validity and Reliability

\begin{tabular}{|c|c|c|c|c|c|}
\hline \multirow[t]{2}{*}{ Variable } & \multirow[t]{2}{*}{ Items } & \multicolumn{2}{|c|}{ Correlation } & \multicolumn{2}{|c|}{ coefficient } \\
\hline & & $\mathbf{r}$ & status & alpha & status \\
\hline \multirow[t]{3}{*}{ Intellectual Capital } & $\mathrm{X} 1.1$ & 0.837 & Valid & \multirow{3}{*}{0.779} & \multirow{3}{*}{ Reliable } \\
\hline & $\mathrm{X} 1.2$ & 0.841 & Valid & & \\
\hline & $\mathrm{X} 1.3$ & 0.822 & Valid & & \\
\hline & $\mathrm{X} 2.1$ & 0.783 & Valid & \multirow{4}{*}{0.852} & \multirow{4}{*}{ Reliable } \\
\hline & $\mathrm{X} 2.2$ & 0.870 & Valid & & \\
\hline & $\mathrm{X} 2.3$ & 0.869 & Valid & & \\
\hline & $\mathrm{X} 2.4$ & 0.836 & Valid & & \\
\hline \multirow[t]{5}{*}{ Superiority Compete } & Y1 & 0.778 & Valid & \multirow{5}{*}{0.803} & \multirow{5}{*}{ Reliable } \\
\hline & $\mathrm{Y} 2$ & 0.763 & Valid & & \\
\hline & Y3 & 0.796 & Valid & & \\
\hline & Y4 & 0.843 & Valid & & \\
\hline & Y5 & 0.638 & Valid & & \\
\hline
\end{tabular}

Based on the results of the validity and reliability tests carried out on instrument items, it shows that all research instrument items are valid and reliable, because they have met the validity testing criteria, namely the Pearson Product Moment Correlation Index (r) 0.3 and the reliability testing criteria, namely the Alpha value. Cronbach 0.6.

\section{Confirmatory Factor Analysis Results}

The results of measurements of the dimensions or indicators of variables that can form latent variables with CFA and the determination of indicators of research variables is based on the value of factor loading. The summary of the results of the CFA test on the indicators that make up the research variables is shown in Table 4.

Table 4. Factors Loading $(\lambda)$ Measuring Research Variables

\begin{tabular}{|c|c|c|c|}
\hline \multicolumn{3}{|c|}{ Indicators and Variables } & \multirow{2}{*}{$\begin{array}{c}\text { factor loading } \\
0.757\end{array}$} \\
\hline Human capital & $-->$ & Intellectual Capital & \\
\hline Structural capital & $-->$ & Intellectual Capital & 0.744 \\
\hline customer capital & $-->$ & Intellectual Capital & 0.650 \\
\hline Knowledge app & $-->$ & & 0.423 \\
\hline Knowledge creation & $-->$ & & 0.690 \\
\hline Knowledge dissemination & $-->$ & & 0.765 \\
\hline Knowledge utilization & $-->$ & & 0.792 \\
\hline Uniqueness & $-->$ & Superiority Compete & 0.691 \\
\hline Rarely found & $-->$ & Superiority Compete & 0.763 \\
\hline Not easy to imitate & $-->$ & Superiority Compete & 0.775 \\
\hline Not easy to replace & $-->$ & Superiority Compete & 0.812 \\
\hline Competitive price & $-->$ & Superiority Compete & 0.736 \\
\hline
\end{tabular}


Based on Table 4, it can be explained that the indicators that make up the intellectual capital variables, namely human capital, structural capital and customer capital have a factor loading (FL) value above 0.5. Thus, all the indicators tested are important indicators as forming intellectual capital. Furthermore, when viewed from the loading factor value of each indicator, the indicator that is considered to have the largest or strongest contribution in forming the intellectual capital variable is human capital.

The indicators that make up the Knowledge Management variable are

Knowledge application, knowledge creation, knowledge dissemination and knowledge utilization have a factor loading (FL) value above 0.5. Thus, all the indicators tested are important indicators as forming Knowledge Management. Furthermore, if it is seen from the loading factor value of each indicator, the indicator that is considered to have the largest or strongest contribution in forming the Knowledge Management variable is the use of knowledge.

The indicators that make up the competitive advantage variable are uniqueness, rare, not easy to imitate, not easy to replace and competitive prices have a factor loading (FL) value above 0.5. Thus, all tested indicators are important indicators as forming competitive advantage. Furthermore, when viewed from the loading factor value of each indicator, the indicators that are considered to have the largest or strongest contribution in forming the competitive advantage variable are not easily replaced.

\section{DISCUSSION}

The intellectual concept is a concept that is formed based on human intelligence, organizational routines, and market relations, each of which is formed in human capital, structural capital, and customer capital (Bontis et al., 2000, Boekestein, 2006). Intellectual capital is knowledge or intangible assets that develop the value of a product or service, thereby contributing to the innovation and creativity of a company's resources.

Based on the results of the Confirmatory Factor Analysis, the indicator that is considered to have the largest or strongest contribution in forming the intellectual capital variable is human capital. Human capital is the main component that must be owned by every type of business because there is innovation, knowledge, skills, and expertise in every individual who enters the company. Human capital as the main resource that adds value in business processes, such as skills, knowledge, expertise, competence, attitude, and agility (Khalique, Shaari, \& Hassan, 2011). The importance of human capital is because there are sources of innovation and strategic renewal that come from every individual in it. Nasih (2011) explains, human capital is a critical resource that exists in every personnel because of the ability to, leverage, direct, manage,

Knowledge management is an important component in business strategy (Iyer and Ravindran, 2009), because the value of HR is becoming increasingly important for an organization's competitive advantage. With knowledge management core and organizational competencies can be centralized and developed (Choong \& Wong, 2010), which covers aspects of the organization's core business processes in increasing organizational effectiveness (Chen \& Hatzakis, 2008).

Based on the results of Confirmatory Factor Analysis, the indicator that is considered to have the largest or strongest contribution to forming the Knowledge Management variable is the use of knowledge. In order to survive in the globalization competition, organizations need to take advantage of the assets owned by the company, especially in terms of knowledge assets. Organizations are expected to be able to approach their resources in a sustainable use of 
knowledge assets. Knowledge is an intangible asset that can help organizations deal with environmental changes. With the right knowledge, organizations can survive in the current global competition. Besides that, with good management, it will provide more value for the organization which will become a competitive advantage for organizations competing in the global market.

Utilization of knowledge can be done by utilizing knowledge about digital marketing which is one of the media that is often used by business actors because of the new ability of consumers to follow the flow of digitization. With digital marketing, communication and transactions can be done any time / real time and can be accessed all over the world, consumers can also view various goods via the internet, most of the information about various products is already available on the internet, ease of ordering and the ability of consumers to compare one product to another (Kotler \& Keller, 2008).

Bharadwaj et al. (1993) explained that competitive advantage is the result of implementing strategies that utilize various company resources. Unique skills and assets are seen as sources of competitive advantage. Competitive advantage is defined as a strategy benefit from companies that cooperate to create a more effective competitive advantage in the market. Competitive advantage basically grows from the values or benefits created by the company for its customers. Bharadwaj et al. (1993) revealed that competitive advantage is measured by indicators of uniqueness, rare, not easy to imitate, not easy to replace, and competitive prices. Bratic (2011) revealed that competitive advantage is measured in four indicators, namely: Price, Quality, Deliver Dependability, product innovation and time to market. Penget et al. (2011) priority measurement consists of cost priority, quality priority, deliver priority, flexibility priority and innovation. Michalic and Buhalis (2013) use image, quality, differentiation, contact and price in seeing competitive advantage. The conceptual framework of research by Li et al. (2006) developed indicators for measuring competitive advantage, namely: price/cost, quality, delivery dependability, product innovation and time to market.

Based on the results of Confirmatory Factor Analysis, indicators that are considered to have the largest or strongest contribution in forming competitive advantage variables are not easily replaced. This means that SMEs will gain a competitive advantage if they are able to produce products that cannot be replaced by competitors.

\section{CONCLUSION}

Based on the results of confirmatory factor analysis, it is explained that the indicators of human capital, structural capital and customer capital are important indicators as forming intellectual capital and the indicator that is considered to have the largest or strongest contribution to form the intellectual capital variable is human capital. Indicators of knowledge application, knowledge creation, knowledge dissemination and knowledge utilization are important indicators as forming Knowledge Management and the indicator that is considered to have the largest or strongest contribution to forming Knowledge Management variables is knowledge utilization. Indicators of uniqueness, rare, not easy to imitate.

Conceptualization: Suharto

\section{AUTHOR CONTRIBUTIONS}

Data Curation: M. Taufiq Noor Rokhman

Formal Analysis: Suharto, M. Taufiq Noor Rokhman

Project Administration: Ahmad Jamil 
Software: M. Taufiq Noor Rokhman

Validation: M.Taufiq Noor Rokhman, Ahmad Jamil

Writing - Original Draft: Suharto, M.Taufiq Noor Rokhman

Writing - Review \& Editing: Suharto, M. Taufiq Noor Rokhman

\section{CONFLICT OF INTEREST STATEMENT}

The authors declare that they have no competing interests.

\section{ACKNOWLEDGEMENT}

This research was carried out by internal grant funding from the University of Wisnuwardhana Malang

\section{REFERENCES}

Akio, T. (2005). The critical assessment of the resource-based view of strategic management: the source of heterogeneity of the firm. Ritsumeikan international affairs, 3(1), 125-150.

Barclay, RO., \& Murray, C.M. (2002). What is knowledge management? Knowledge Praxis, Retrieved from from http://www.media-access.com/whatis.html

Barney, J. B., \& Clark, D. N. (2007). Resource-based theory: Creating and sustaining competitive advantage. Oxford University Press on Demand.

Bharadwaj, S. G., Varadarajan, P. R., \& Fahy, J. (1993). Sustainable competitive advantage in service industries: a conceptual model and research propositions. Journal of marketing, 57(4), 83-99.

Boekestein, B. (2006). The relation between intellectual capital and intangible assets of pharmaceutical companies. Journal of Intellectual Capital.

Bontis, N., \& Fitz-enz, J. (2002). Intellectual capital ROI: a causal map of human capital antecedents and consequents. Journal of Intellectual capital.

Bontis, N., Keow, W. C. C., \& Richardson, S. (2000). Intellectual capital and business performance in Malaysian industries. Journal of intellectual capital.

Bratianu, C., \& Orzea, I. (2010). Organizational knowledge creation. Management \& Marketing, $5(3)$.

Bratić, D. (2011). Achieving a competitive advantage by SCM. IBIMA Business Review, 2011, 1-13.

Bukh, P. N., Nielsen, C., Gormsen, P., \& Mouritsen, J. (2005). Disclosure of information on intellectual capital in Danish IPO prospectuses. Accounting, Auditing \& Accountability Journal.

Chahal, H., \& Bakshi, P. (2015). Examining intellectual capital and competitive advantage relationship: Role of innovation and organizational learning. International Journal of 


\section{Bank Marketing.}

Chen, C. J., Huang, J. W., \& Hsiao, Y. C. (2010). Knowledge management and innovativeness: The role of organizational climate and structure. International Journal of Manpower.

Gold, A. H., Malhotra, A., \& Segars, A. H. (2001). Knowledge management: An organizational capabilities perspective. Journal of management information systems, 18(1), 185-214.

Honeycutt, J. (2000). Knowledge Management Strategies: Strategi Manajemen Pengetahuan. Jakarta: PT. Alex Media Komputindo.

Ireland, R. D., Hitt, M. A., \& Sirmon, D. G. (2003). A model of strategic entrepreneurship: The construct and its dimensions. Journal of management, 29(6), 963-989.

Li, S., Ragu-Nathan, B., Ragu-Nathan, T. S., \& Rao, S. S. (2006). The impact of supply chain management practices on competitive advantage and organizational performance. Omega, 34(2), 107-124.

Meso, P., \& Smith, R. (2000). A resource-based view of organizational knowledge management systems. Journal of knowledge management.

Mihalic, T., \& Buhalis, D. (2013). ICT as a new competitive advantage factor-case of small transitional hotel sector. Economic and business review, 15(1), 33-56.

Mills, A. M., \& Smith, T. A. (2011). Knowledge management and organizational performance: a decomposed view. Journal of knowledge management.

Petty, R., \& Guthrie, J. (2000). Intellectual capital literature review: measurement, reporting and management. Journal of intellectual capital.

Wang, W. Y., \& Chang, C. (2005). Intellectual capital and performance in causal models: Evidence from the information technology industry in Taiwan. Journal of intellectual capital.

Williams, S. M. (2001). Is intellectual capital performance and disclosure practices related?. Journal of Intellectual capital.

\section{Copyrights}

Copyright for this article is retained by the author(s), with first publication rights granted to the journal. This is an open-access article distributed under the terms and conditions of the Creative Commons Attribution license (https://creativecommons.org/licenses/by/4.0). 